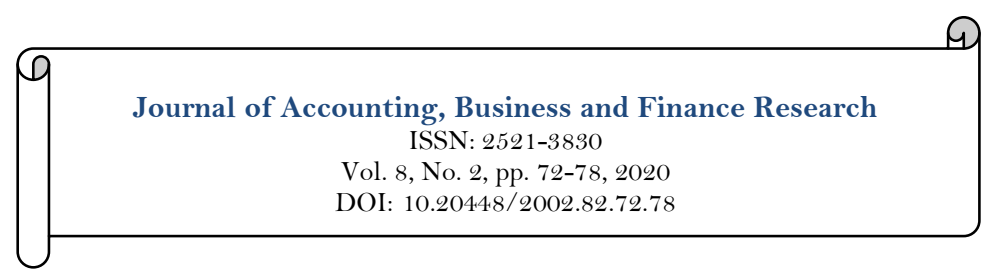
$\checkmark$ check for

\title{
Organizational Capital and Financial Performance; What is the Mediation Effect of Firm Innovation: Evidence from Insurance Firms in Kenya
}

\author{
Tecla Kirwa ${ }^{1^{*}}$ \\ Vincent Ngeno ${ }^{2}$ \\ 'Department of Accounting and Finance, Kibabii University, Bungoma, Kenya. \\ Email:teclakirwa@yahoo.com \\ ${ }^{2}$ Department of Agricultural Economics, Moi University, Eldoret Kenya.
}

\section{Abstract}

Purpose: following the Resource Based View Theory, this study explored whether firm innovation mediated the upshot of organization capital on firm performance in Kenyan insurance firms. Design / Methodology: the research surveyed 49 insurance firms in Kenya using explanatory research design. The hypotheses testing used Structural Equation Modelling. Findings: The outcome revealed that organization capital positively influences firm innovativeness and that firm innovation partially arbitrates the association between organization capital and performance of the firm. Practical implication: the outcome of the research suggested that for insurance firms to be innovative organization capital should be enhanced in terms of availability in the systems, databases, files, licenses or patents which is termed very important for implementation of innovation since such knowledge is the result of humdrum routine of employees, reminds usage process, flexible in usage for new contexts and more significantly it improves employees technology skills thus resulting to a better performance by the firm.
Keywords: Organisation capital

Financial performance Firm innovation

Resource-based view.

Licensed:

This work is licensed under a

Creative Commons Attribution 4.0

License.

Publisher:

Scientific Publishing Institute

Accepted: 16 January 2020

Published: 3 February 2020

Funding: This study received no specific financial support.

Competing Interests: The authors declare that they have no competing interests.

Acknowledgement: The authors acknowledge the contribution and the scholarly support from School of Business and

Economics - Moi University.

\section{Introduction}

Performance in finances is the greatest significant pointer of a successful firm. Intense worldwide competition as a characteristic of the present business setting has produced a higher uncertainty level amongst companies in entire industries (Gavrea, Ilies, \& Stegerean, 2011). This hyper-competition needs constantly superior performance being the focal point of every organization this is because the growth and progress of an organization can only be through performance. Beyond the matchmaking function, the firms' financial performance posses critical effects on the growth of the economy of various countries. Investment of stakeholders are rewarded by good financial performance (Palaniappan, 2017). In turn, this will encourage surplus investment and leads to growth in economic.

Therefore, in the current economic context knowing the determinant of the organization performance is important this enables to identify factors that need to be treated with greater interest to help improve the financial performance. It is progressively acknowledged that any organization performance, is largely reliant on its organization capital which is linked directly to available knowledge within the systems, databases, files, patents or licenses and is important for implementation of innovation (Zahra, Ucbasaran, \& Newey, 2009). Development of organizational capital depend on the established knowledge storing devices and organized, recurrent practices which may lead to firm innovativeness if well managed. The key role of organization capital is to bring together the organization's resources and link it to the processes that produces firm value. The success of business competition is fundamental to the strategic management of its organization capital 
through appropriate storage of institutionalized knowledge in database, routines and structures making them freely accessible to members of the organization who utilize it towards innovativeness.

Although existing scholars have explained the association between organization capital and firm innovation (Al-Dujaili, 2012; Allameh, Abbasi, \& Shokrani, 2010; Ghorbani, Mofaredi, \& Bashiriyan, 2012) their research have produced mixed result. Amiri, Jandaghi, and Ramezan (2011) found that capital of organization is clearly connected to increment innovation, and also to the radical innovation, in the contrary, Kontic and Cabrilo (2009) finished by mentioning the innovation development process/product, as well as, research and development were not perceived as crucial impelling factors in organization capital.

Additionally early investigations have recorded the effect of organization capital on firm innovativeness (Al-Dujaili, 2012; Kamukama, Ahiauzu, \& Ntayi, 2010) while other scholars have explained the association between organization capital and firm performance (Khalique, Nassir Shaari, Isa, \& Ageel, 2011; Mosavi, Nekoueizadeh, \& Ghaedi, 2012) the link between firm innovativeness, organization capital and firm performance are rare in literature. Thus, the study examined the importance of firm innovation, and its influence on the effect of organization capital and firm performance. This aspect was hypothesized to mediate the connection between organization capital and firm performance.

\section{Literature Review}

\subsection{The Kenyan Perspective}

The Global Innovation Index (GII) ranked Kenya at position 78 globally in 2018, which is the third highest ranking in Africa. This was attributed to innovation linkages and transfer of creative services among others. One of the most notable innovations in the Kenyan financial sector is the roll out of mobile phone financial services. Cruz, Neto, Munoz-Gallego, and Laukkanen (2010) pointed out that banking with takes care of monetary transactions by use of mobile devices. Insurance as a segment is no exception to such progresses, with the arising of new methods of providing services, great chances of collecting data and detecting fraud that can open ways to better ways of identifying risks and how to mitigate them, which are being referred to as "Insure-Tech". Over the years, the insurance industry in Kenya has worked hard at reclaiming its rightful image through embracing a new strategies that can enable the industry gain competitive advantage. There is competition among insurance firms for the limited market with very low penetration. In Kenya both at personal and corporate level insurance coverage remains predominantly on industrial, fire, personal accident and motor (commonly grouping medical cover) classes. This demonstrates an inferior approach towards individual insurance cover in general. Per available debt calamity in 2011, a notable drop was witnessed in the overall premiums, a claims increase and an investment income decline. The gross direct premium income dropped from 25\% in 2010 to $18 \%$ in 2011 (Insurance Regulatory Authority, 2011). This pushed companies, specifically those conducting non-life business to adjust their strategies in order to increase performance and gain competitive advantage (IRA, 2011).

Insurance firms have consequently turned their attention on innovation to allow them respond to, and compete efficiently in the market. Some insurance companies in Kenya have adopted several distinctive features to counter competition and elevate them among other industry players. The use of technology, especially the mobile phone to disseminate information and facilitate premium and claim payments is particularly an area of interest to insurance companies. Other insurance companies have tailored certain services and products to encounter the individual demands of their clients, as well as being open to new channels of distribution of insurance like banc assurance that bring them closer to their target markets (AKI, 2014). With the spread of smart phones and other software tools in a number of insurers in Kenya have apps for their clients. Data technology has enabled insurance firms to have many sources from where they can collect data and help create personalized products. Technologies such as Internet of Things and others provide and modify business models for competitive advantage. For example, data captured through internet of things can help define insurance industry's transformation in lines of underwriting polices and risk management procedures.

Nevertheless, despite the documented significance and a widespread descriptive literature of firm innovations, there have been unexpectedly few empirical studies in relation to organization capital. This state has deprived insurance firms the much required information concerning this important area of organization capital and firm innovations sometimes leading to contrary causation in the innovation-performance relationship and thus the need for this study. Further, attempts to integrate research on organization capital, innovation and financial performance are rare. Based on this, examining the link between firm innovation, structural capital and performance in terms of finance in Kenyan insurance companies can thus be considered a topical issue, thus the need for this study. Thus, the study hypothesized that;

\subsection{Organization Capital and Firm Innovation}

Organisational capital is structural elements of organisational culture that are independent of employees. It consist of business processes and system, commitments and rules norms and relationships that enable tangible and intangible resources to be productive. Investment in organizational capital investment uses up resources, this will bring a long-term improvement in productivity, the well- being of the worker, or social 
performance through modifications in the functioning of the organization (Tomer, 1987). Organizational capital concept has a great value because it links the insights behaviour of the organization in regard to the contribution of the structure of the organization, climate, culture, patterns of interaction, socialization, etc. to the innovation and productivity (Tomer, 1987).

An organization capital principal role is linking the resources belonging to the organization together to processes that will generate customers value and sustain competitive advantage of the firm (Dess \& Picken, 1999). Ghorbani et al. (2012) established of being a significant association betwixt the organization organizational innovation and capital management. Also Al-Dujaili (2012) stated that the capital of an organization has a significant effect upon the innovation of the organization. Allameh et al. (2010) said that the capital of the organization positively affects the learning capability of organization.

Consequently, organisation capital may enable members of the organisation to come up with novel ideas and suggestions that support innovation (Nonaka, 1994). Organizational capital can strengthen knowledge that prevails and therefore influence an organization's incremental in innovative capabilities. Thus, the study hypothesized that:

Ho1: Organization Capital positively influence firm innovation.

\subsection{Effect of Firm Innovation on Organization Capital and Firm Performance}

Organizational capital notion has abundant value this because it links organizational behaviour insights in regard to the contribution of culture, climate organizational structure, patterns of interaction, socialization, etc. to the innovation and productivity (Tomer, 1987). An organization capital principal role is linking the assets of the organization collectively into processes that will generate value for customers' and sustain competitive advantage of the firm (Dess \& Picken, 1999). With proper managing of organizational capital, where by codified experiences and knowledge are institutionalized and stored appropriately in databank, structures, routines and readily accessible for firm members, enabling the firms to utilize the knowledge and act towards innovations that are successful.

Naturally, organizational capital is codified. Structured and repetitive deeds enable the formation, conservation and enhancement of organizational capital (Nelson \& Winter, 1982). Codification of organizational capital is reproduced in guidebooks, databanks, patents, structures and procedures, as well as in mandated processes and rubrics on accessing, sharing and utilizing knowledge. Consequently, information exchanges in organizational capital are as a subject to a well guidelines that have been established. The growth of organizational capital depend on the creation of knowledge databanks and well structured, regular practices that may lead to innovative firm if the management is well done. Organizational capital enhances the reinforcement of existing knowledge therefore influencing the organizations incremental innovation abilities. The organization preserved knowledge and also the intrinsic value of the organization can be improved depending on relationships, interactions quality and collaborations amidst groups of individuals who operate within this conserved knowledge. When setting up knowledge in organizations groups perform significant (Nonaka, 1994) and the quality of the team and group work not only improves how an organization's codified knowledge in patents, databases, and licenses is leveraged, but also how the sources of knowledge are updated and reinforced.

Ghorbani et al. (2012) found out of a substantial connection betwixt management of organizational capital and organizational innovation. Also Al-Dujaili (2012) stated that organizational capital have significant impact upon organizational innovation. Allameh et al. (2010) believed that the capital of organization confidently have an influence on organizational ability to learn. Amiri et al. (2011) found that organizational capital is clearly connected to the radical innovation and incremental. Kamukama et al. (2010) stated of existing a solid connection betwixt innovation capital and structural capital, and a solid link betwixt the structural capital and business performance. In contrary, Kontic and Cabrilo (2009) finished by saying that product/process innovation development, in addition as, research and development were not considered as vital influencing aspects in structural capital. Whereas, Maria Diez, Ochoa, Prieto, and Santidrian (2010) believed that structural capital does not only strengthens and empowers human capital; but also discloses organizations aptitude to pass on and store intellectual material. Additionally, Gruian (2011) disclosed that companies that have great efficiency structural capital will definitely have a better performance in finance. Khalique et al. (2011) showed that customer capital and structural capital have positive association with the organizational performance. Finally, Mosavi et al. (2012) in conclusion said that with greater structural capital efficiency companies have greater ratios when it comes to value of market-to-book, and have better performance finance.

While it is clear from writings that knowledge that is institutionalized collected in and applied through an organization patents, databases structures systems and processes seems to help in reinforcing prevailing knowledge resulting to incremental innovation and that organizational capital significantly affects firm performance, then there is a possibility that having such efforts to enhance innovation might result into organization capital influencing firm performance. Thus, the study hypothesized that:

Ho2: firm innovation mediates the effect of organization capital on firm performance. 


\section{Research Methodology}

The current study was based positivism research philosophy while employing explanatory study design. 372 respondents were selected as a sample size from population of 5273 employees of 49 insurance firms registered with Insurance Regulatory Authority (IRA) in Kenya (Insurance Regulatory Authority, 2014) using stratified and random sampling. Primary data was used after being collected by use of structured questionnaires with closed ended questions to collect information on organisation capital, firm innovation and firm performance of insurance firms in Kenya. For the purposes of this study, a seven point Likert scale $(1=$ strongly disagree to $7=$ strongly agree) was developed for rating responses of independent and dependent.

\subsection{Reliability and Validity}

Validity of the items in the questionnaire was ascertained by adapting the measurement scales previous tested by different researchers. Innovation was measured on instrument used by Wu, Chang, and Chen (2008); Subramaniam and Youndt (2005) and Tarus and Sitienei (2015). Organisation capital was measured by adapting instrument used by Tayles, Pike, and Sofian (2007) as well as Subramaniam and Youndt (2005) while firm performance was measured based on balance score card approach and fall in the perspective of financial performance (Atkison, Kaplan, Matsumura, \& Young, 2007). Cronbach's alpha were used to assess the reliability of the instrument. Outcome of the study showed that all the coefficients were above 0.7 hence, the instruments were considered reliable as their reliability coefficients were above the recommended 0.7 threshold (Fraenkel \& Wallen, 2000).

\subsection{Measurement Model}

The best method of structural equation model (SEM) framework for testing indirect effects is biascorrected bootstrapping, Shrout and Bolger (2002). Two process were followed by SEM: validating the measurement model through conducting confirmatory factor analysis, and fitting the structural model through path analysis with latent variables using AMOS version 5. Kline (1998) proposed a two-step modelling process and urges SEM researchers to test the pure measurement model underlying a full structural equation model, and if the fit of the measurement model is found acceptable, then the structural model is tested. From the study, the dependent variable is firm performance while the independent variable organisation capital. The mediating variable is firm innovation. The model estimated is specified below:

Model one below represents the equation of the direct effect

$$
\mathrm{FI}=\beta_{\mathrm{o}}+\beta_{1} \mathrm{OC}+\boldsymbol{\varepsilon}
$$

The mediating model is estimated as follows;

$$
\mathrm{FP}=\beta_{\mathrm{o}}+\beta_{1} \mathrm{OC}+\beta_{2} \mathrm{FI}+\boldsymbol{\varepsilon}
$$

Where;

FI (Firm Innovation), OC (Organization Capital) and FP (Financial Performance).

4. Results

Table 1 presented the means, standard deviations, and correlation between all variables in the study. From the outcomes, an important correlation betwixt organization capital, firm innovation and firm performance was depicted.

\begin{tabular}{c|c|c|c|c|c}
\multicolumn{7}{c}{ Table-1. Descriptive statistics. } \\
\hline Variables & Mean & Std. Deviation & $\mathbf{1}$ & $\mathbf{2}$ & $\mathbf{3}$ \\
\hline 1 & 5.44 & 0.89 & 1 & & \\
\hline 2 & 5.80 & 0.79 & $.597^{* *}$ & 1 & \\
\hline 3 & 5.57 & 0.82 & $.764^{* *}$ & $.713^{* *}$ & 1 \\
\hline $\begin{array}{l}\text { Note: ** correlation significant at 0.01 level(2-tailed) } \\
1 \quad=\end{array}$ \\
$2=$ \\
$3=$ \\
$3=$
\end{tabular}

\subsection{Testing of hypotheses}

The study established the mediating influence of innovation on organization capital and financial performance of insurance firms. A SEM mediation analysis was done using the Baron and Kenny (1986) causal-steps approach; Let's assume that the indirect model gives a better or acceptable fit than the model that is direct, perform the bootstrapping test and observe the importance of the direct effect, independent variable and mediator 'path a', direct outcome of mediator and dependent variable 'path b', and indirect effect 'a*b'. Assuming that paths ' $a$ ' and ' $b$ ' are significant, the mediation effect is confirmed if the results of the bootstrapping test showed that the value of the indirect effect ' $a * b$ ' is different from zero and the $p$-value is significant. If c' is closer to zero compared to c and non-significant, one can conclude that the mediating 
variable completely mediates the effect between independent variable and dependent variable. On the other hand, if c' is still significant the researcher concludes there is partial mediation of independent variable on dependent variable.

Table-2. Estimates of effect of firm innovation on the relationship between organization capital and firm performance.

\begin{tabular}{|c|c|c|c|c|}
\hline Structural Paths & Estimate & S.E & C.R & $\mathbf{P}$ \\
\hline \multicolumn{5}{|l|}{ Direct Model } \\
\hline Firm Performance $\leftarrow$ Organization Capital & .035 & .090 & 0.391 & .000 \\
\hline \multicolumn{5}{|l|}{ Indirect Model } \\
\hline Financial Performance $\leftarrow$ Innovation & .707 & .052 & 13.718 & .000 \\
\hline Firm Innovation $\leftarrow$ Organization Capital & .979 & .089 & 11.045 & .000 \\
\hline Financial Performance $\leftarrow$ Innovation $\leftarrow$ Organization Capital & .701 & .076 & 9.213 & .012 \\
\hline
\end{tabular}

Table 2 above shows the results of the findings. The study hypothesized that organization capital positively affect firm innovation. The research findings depicts that organization had a positive and significant effect on firm innovation $((\beta=.979, \rho<.05)$. thus, the hypothesis failed to be rejected. Hypothesis 2 proposed that firm innovation would positively and significantly mediate the effect of organization capital on firm performance. Following (Baron \& Kenny, 1986) procedures in establishing mediation, the study findings postulates that direct relationship between organization capital and firm performance was significant at $(\beta$ $=.035, \rho<.05)$ and that direct relationship between organization capital and firm innovations is significant at $(\beta$ $=.979, \rho<.05)$ and that firm innovation had significant influence on financial performance $(\beta=.701, \rho<.05)$ when both organization capital and firm innovation are predictors of financial performance. Based on the results of the SEM analysis it is shown that firm innovation met the criteria as a partial mediating variable. Thus the hypothesis failed to be rejected. The total effects is summarized in path diagram, as indicated in Figure 1.

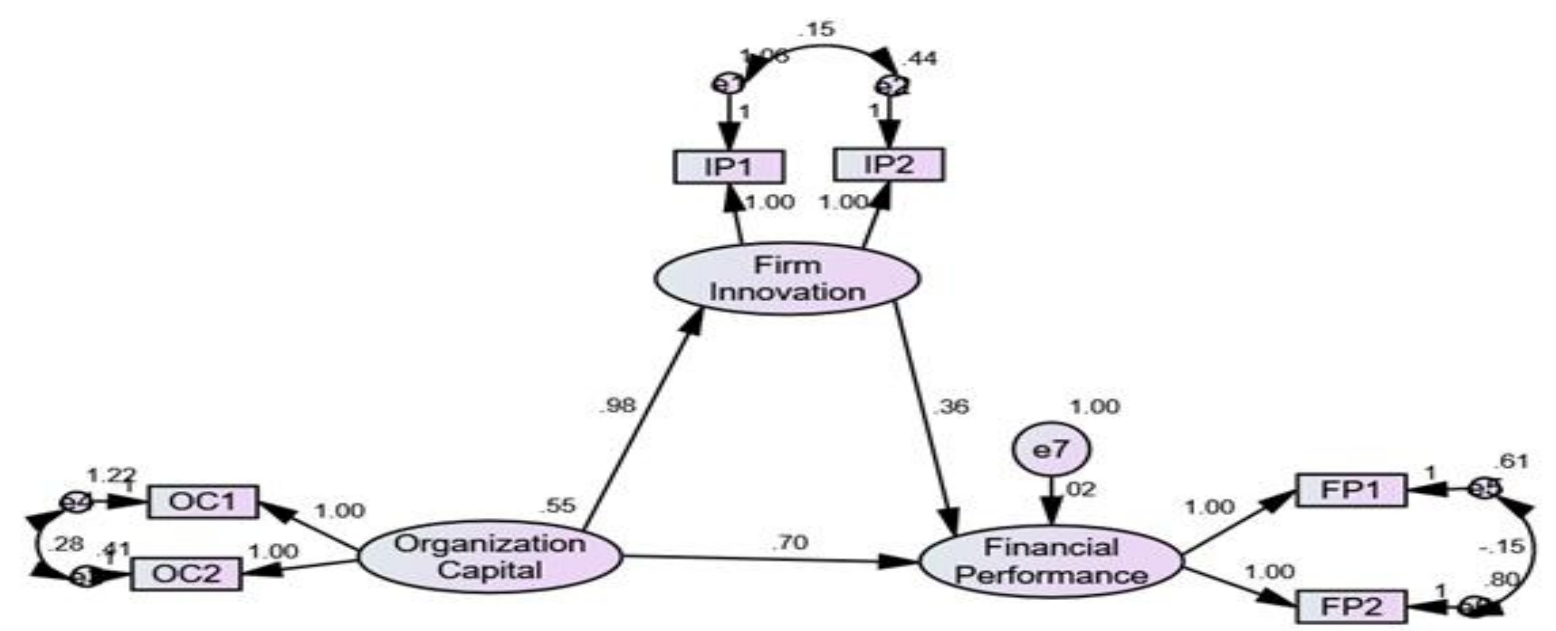

Chi square $(\boldsymbol{\chi} \mathbf{2})=45.733(P<0.01)$, Normed Fit Index=.941, Comparative Fit index=.966, Tucker Lewis

Index=.937, Root Mean Square Error of Appropriation $=.04$

Figure-1. SEM for mediating effect of firm innovation on organizational capital-financial performance relationship.

\section{Discussion}

Following the resource based view theory; this research looked at the arbitrating role of firm innovation on the association between organization capital and the performance of the insurance firms in Kenya. Through the study it was established that organization capital is key component to firm innovation and that innovation of the firm partly mediates the relationship between organization capital and performance of the firm. This SEM outcome of this study are consistent with the findings of Ghorbani et al. (2012). Organizational capital being knowledge which is accumulated and stored in databases, proceedings, patents, licenses, trademarks, manuals and organizational structures is also a key aspect in firm innovation. Further, there is possibility that some dimensions of organization capital might have a greater reliance on firm innovation to extend their effects to firm financial performance. This is so because established processes and routines leveraging organizations preserved knowledge influences positive innovative capabilities of an organization hence affecting the financial performance (Landry, Amara, \& Lamari, 2002). 


\section{Conclusion}

The findings agree with resource based view theory that organisation capital is a key resource that influence firm innovativeness and that firm innovation arbitrates the outcome of organisation capital on performance of the firm. Organizational capital being that knowledge that has been gathered and kept in databases, proceedings, patents, licenses, trademarks, manuals and organizational structures is also a key aspect in firm innovation. It alludes to the intellectual asset that remain even after employees have left the company. It does not depend on individuals and is generally explicit (Hormiga, Batista-Canino, \& SánchezMedina, 2011). Strong and unique organization capital in terms of effective routines procedures and processes provide a potential source for innovative performance in organizations.

The results that organization knowledge stored in procedures, structures and processes of the organisation enables employees to be innovative. Further, the results offer critical understanding that when firm innovativeness is enhanced the organization capital of the firm greatly improves firm performance. Therefore, insurance firms need to actively engage in the development of new products and services so as to capture new markets and strengthen on the existing ones. The firm's product lines need to be extended as it will have an influence that is positive on financial performance. For the managers, they should develop and adopt innovations that are geared towards improving their financial performance. Finally, the management of insurance firms should empower their employees through motivation strategies that can make them become more innovative. In addition, the insurance firms should enhance innovation strategies among their capital resources in order to enhance their performance.

\section{References}

Al-Dujaili, M. A. (2012). Influence of intellectual capital in the organizationalInnovation. International Journal of Innovation, Management and Technology, 3(2), 128-135.

Allameh, S. M., Abbasi, S., \& Shokrani, S. A. (2010). The mediating role of organizational learning capability between intellectual capital and job satisfaction. European Journal of Social Sciences, 17(1), 125-136.

Amiri, A. N., Jandaghi, G., \& Ramezan, M. (2011). An investigation to the impact of intellectual capital on organizational innovation. European Journal of Scientific Research, 64(3), 472-477.

Atkison, A. A., Kaplan, R. S., Matsumura, E. M., \& Young, S. M. (2007). Management accounting (5th ed.). New Jersey: Person Prentice Hall.

Baron, R. M., \& Kenny, D. A. (1986). The moderator-mediator variable distinction in social psychological research: Conceptual, strategic, and statistical considerations. Journal of Personality and Social Psychology, 51(6), 11731182.Available at: https://doi.org/10.1037/0022-3514.51.6.1173.

Cruz, P., Neto, L. B. F., Munoz-Gallego, P., \& Laukkanen, T. (2010). Mobile banking rollout in emerging markets: Evidence from Brazil. The International Journal of Bank Marketing, 28(5), 342-371.Available at: https://doi.org/10.1108/02652321011064881.

Dess, G. D., \& Picken, J. C. (1999). Beyond productivity: How leading companies achieve superior performance by leveraging their human capital. New York: American Management Association.

Fraenkel, J. R., \& Wallen, N. E. (2000). How to design and evaluate research in education. New York: McGraw.

Gavrea, C., Ilies, L., \& Stegerean, R. (2011). Determinants of organizational performance: The case of Romania. Management \& Marketing Challenges for the Knowledge Society, 6(2), 285-300.

Ghorbani, M., Mofaredi, B., \& Bashiriyan, S. (2012). Study of the relationship between intellectual capital management and organizational innovation in the banks. African Journal of Business Management, 6(15), 5208-5217.

Gruian, C. M. (2011). The Influence of intellectual capital on Romanian Companies' financial performance. Annales Universitatis Apulensis Series Oeconomica, 13(2), 260-272.

Hormiga, E., Batista-Canino, R. M., \& Sánchez-Medina, A. (2011). The role of intellectual capital in the success of new ventures. International Entrepreneurship and Management Journal, 7(1), 71-92.Available at: https://doi.org/10.1007/s11365-010-0139-y.

Insurance Regulatory Authority. (2011). Annual Report on Performance of Insurance Companies :Nairobi; Government Pinter.

Insurance Regulatory Authority. (2014). Annual Report on Insurance Industry: Nairobi; Government Printer.

Kamukama, N., Ahiauzu, A., \& Ntayi, J. M. (2010). Intellectual capital and performance: Testing interaction effects. Journal of Intellectual Capital, 11(4), 554-574.Available at: https://doi.org/10.1108/14691931011085687.

Khalique, M., Nassir Shaari, J. A., Isa, A. H. B. M., \& Ageel, A. (2011). Relationship of intellectual capital with the organizational performance of pharmaceutical companies in Pakistan. Australian Journal of Basic and Applied Sciences, 5(12), 1964-1969.

Kline, R. B. (1998). Software review: Software programs for structural equation modeling: Amos, EQS, and LISREL. Journal of Psychoeducational Assessment, 16(4), 343-364.Available at: https://doi.org/10.1177/073428299801600407.

Kontic, L., \& Cabrilo, S. (2009). A strategic model for measuring intellectual capital in Siberian industrial enterprises. Economic Annals, LIV(183), 89-117.

Landry, R., Amara, N., \& Lamari, M. (2002). Does social capital determine innovation? To what extent? Technological Forecasting and Social Change, 69(7), 681-701.Available at: https://doi.org/10.1016/s0040-1625(01)00170-6.

Maria Diez, J., Ochoa, M. L., Prieto, M. B., \& Santidrian, A. (2010). Intellectual capital and value creation in Spanish firms. Journal of Intellectual Capital, 11(3), 348-367.Available at: https://doi.org/10.1108/14691931011064581. 
Mosavi, S. A., Nekoueizadeh, S., \& Ghaedi, M. (2012). A study of relations between intellectual capital components, market value and finance performance. African Journal of Business Management, 6(4), 1396-1403.Available at: https://doi.org/10.5897/ajbm11.1466.

Nelson, R. R., \& Winter, S. G. (1982). The Schumpeterian tradeoff revisited. The American Economic Review, 72(1), 114-132.

Nonaka, I. (1994). A dynamic theory of organizational knowledge creation. Organization Science, 5(1), 14-37.Available at: https://doi.org/10.1287/orsc.5.1.14.

Palaniappan, G. (2017). Determinants of corporate financial performance relating to board characteristics of corporate governance in Indian manufacturing industry. European Journal of Management and Business Economics, 26(1), 6784.

Shrout, P. E., \& Bolger, N. (2002). Mediation in experimental and nonexperimental studies: New procedures and recommendations. Psychological Methods, 7(4), 422-445.Available at: https://doi.org/10.1037/1082-989x.7.4.422.

Subramaniam, M., \& Youndt, M. A. (2005). The influence of intellectual capital on the types of innovative capabilities. Academy of Management Journal, 48(3), 450-463.Available at: https://doi.org/10.5465/amj.2005.17407911.

Tarus, D. K., \& Sitienei, E. K. (2015). Intellectual capitaland innovativeness in software development firms: The moderating role of firm size. Journal of African Business, 16(1-2), 48-65.Available at: https://doi.org/10.1080/15228916.2015.1061284.

Tayles, M., Pike, R. H., \& Sofian, S. (2007). Intellectual capital, management accounting practices and corporate performance: Perceptions of managers. Accounting Auditing \& Accountability Journal, 20(4), 522-548.Available at: https://doi.org/10.1108/09513570710762575.

Tomer, J. F. (1987). Organizational capital: The path to higher productivity and well-being. Praeger Publisher.

Wu, W.-Y., Chang, M.-L., \& Chen, C.-W. (2008). Promoting innovation through the accumulation of intellectual capital, social capital, and entrepreneurial orientation. $R$ छ $D$ Management, 38(3), 265-277.Available at: https://doi.org/10.1111/1467-9914.00120-i1.

Zahra, S. A., Ucbasaran, D., \& Newey, L. R. (2009). Social knowledge and SMEs' innovative gains from internationalization. European Management Review, 6(2), 81-93.Available at: https://doi.org/10.1057/emr.2009.6. 